\title{
status and targets for rebuilding the three major fish stocks in Lake victoria
}

Laban Musinguzi*, Mark Olokotum \& Vianny Natugonza

National Fisheries Resources Research Institute, P.0. Box, 343, Jinja, Uganda

"Corresponding author: labanmusinguzi@firi.go.ug

\section{Abstract}

We determined fisheries management reference points for three major fish stocks in Lake Victoria (Nile tilapia, Nile perch and Dagaa)

for Uganda and the whole 1ake. The aim was to ascertain stock status and define reasonable objectives and targets for rebuilding to sustainable leve1s. Dagaa was found to be healthy in Uganda and the whole lake but tending to overfished status. In Uganda, the stock status of Nile tilapia and Nile perch was recruitment impaired but tending more towards collapsed and overfished status respectively. In the whole lake, the stock status of Nile tilapia and Nile perch was collapsed and overfished respectively with the latter tending more towards recruitment impaired. Estimates of maximum sustainable yield (MSY) showed that catches could be increased under good management. Rebuilding the Nile tilapia and Nile perch stock biomasses to MSY leve1 ( $B_{\text {msy }}$ ) could respectively increase the catches above the current 1 eve 1 by $9.2 \%$ and $29.5 \%$ in Uganda and by $72.8 \%$ and $15.1 \%$ in the whole 1 ake. The immediate objective for fisheries management should be to rebuild biomass for the Nile tilapia and Nile perch stocks to $B_{m s y}$. Elimination of $i 11$ egal fishing practices has proved to be effective. In addition, management needs to keep catches at 1 ow 1 evels until biomass for the stocks is $\geq B_{m s}$ for at least three consecutive years.

\section{Introduction}

Uganda and Tanzania have since 2017 strengthened enforcement of fisheries regulations to end illegal fishing and improve stocks of Lake Victoria. With $\sim 1$ million tons of fish produced annual1y, Lake victoria supports the world's biggest inland fishery useful for foreign exchange, employment and direct sustenance of $>4$ mi11ion people (Marsha11 \& Mkumbo 2011). These benefits have for a long time been threatened by high fishing pressure (Njiru et a1, 2007; Nyamweya et a1. 2020), justifying the strengthened enforcement. 
40

The countries strengthened the enforcement by deploying their respective defense forces, Fish Protection Unit (FPU) in Uganda and the multisector task force in Tanzania (Mud7iar, 2018; NPA, 2019). These partial1y or fully replaced previous institutional arrangements such as beach management units which were considered ineffective because of corruption (Nunan et a7. 2018). In Uganda, the enforcement demonstrated determination to end 111 egal fishing practices as the deployment was followed by a total stop on a11 forms of illegalities. The ineffective institutional arrangements were replaced, I1legal gears and crafts destroyed, fishers forced out of near shore areas.

Positive outcomes have been observed from the enforcement. Data from fishery independent surveys conducted since 2017 show that the biomass of Nile perch (Lates nilotics (Linnaeus, 1758)), the most important commercial fish species in the lake has improved and was at its record high since 2010 (Hydro-acoustics Regional working Group, 2019). Interesting $7 y, 48 \%$ of the increase was recorded between 2018 and 2019, with the largest increase recorded in the Ugandan part followed by Tanzania. The increase in biomass was least in Kenya where enforcement was not strengthened. The surveys further showed that although Nile perch was still dominated by individuals under the size at which recruitment to the fishery occurs, there was a record increase in the proportion of fish at the preferred size. These observations suggest that good management in Lake Victoria can pay off.

With a11 due respect, the enforcement is ongoing with no consideration of fisheries management reference points, lacking clear management objectives and targets beyond the elimination of the illegal fishing gears and practices. To contribute to effective enforcement, we estimated fisheries management reference points for major commercial fish species to act as a basis of adopting evidence-based fisheries management objectives and targets. The reference points determined for the whole lake and the Ugandan part of the lake clarify on the status of the stocks before the commencement of the enforcement. They are not only useful for substantiating objectives and targets for the enforcement but are also indispensable for evaluating its effectiveness. At the global scale, this assessment is commensurate with calls to increase assessment of in 1 and fish stocks to support responsible in 1 and fisheries (Cooke et a7. 2016, FAO \& MSU, 2015; FAO, 2020). 


\section{Methods}

\section{Approach and stocks assessed}

The reference points were based on two methods, a Monte carlo method (CMSY) and a Bayesian state-space implementation of the Schaefer production mode1 (BSM). A brief background to these methods is provided here while more details are available in Froese et al. (2017). The methods are built on a principal that catch from a species is produced by its biomass and productivity such that if two of the three parameters are known, production models can be used to estimate the other. The CMSY uses catch and productivity to estimate biomass. The method uses prior ranges of productivity and current biomass (B) relative to unexploited biomass (k) $(B / k)$ at the start, intermediate and end of a time series to detect productivity and unexploited biomass pairs with corresponding biomass estimates that are compatible with observed catches. The BSM on the other hand uses catch and biomass data to estimate productivity. The methods are integrated with other empirical formulae to estimate the reference points including maximum sustainable yield (MSY), fishing mortality rate $F$ at MSY $\left(F_{m s y}\right)$, biomass required to support MSY $\left(B_{m s y}\right)$, relative stock size $\left(B / B_{m s y}\right)$ and exploitation $\left(F / F_{m s y}\right)$.

We estimated reference points for three major stocks in Lake Victoria at two spatial scales: the whole lake and the Ugandan part of the 1ake. Nile perch, oreochromis niloticus (Linnaeus, 1758) (Nile tilapia) and Rastrineobola argentea (Pellegrin, 1904) 1ocal1y known as Dagaa are the three major fish species supporting commercial fisheries in Lake Victoria. The species are responsible for $>88.7 \%$ (estimated from catch used in this study) of catches from

111 Lake Victoria. Dagaa is the most important by weight, followed by 112 Nile perch and Nile tilapia. Nile perch supports fish processing 113 industries that export to foreign markets including the European Union and is the most important by value. 


\section{Data requirements, sources and application to CMSY}

To estimate the reference points, abundance and catch data were required at the two spatial scales. For the whole lake, we estimated the reference points using two indices of abundance i.e. absolute biomass and fishery independent catch per unit effort (CPUE). This provided an opportunity to evaluate the usefulness of both sets of data which are available for Lake victoria. The reference points for the Ugandan part of the lake were based on CPUE only.

The absolute biomass was obtained from Nyamweya et a1. (2016) who simulated the biomass based on catches and hydrodynamics of the 1ake using ecosystem models. This was available to 2015, starting from 1965, 1968 and 1971 for Nile perch, Dagaa and Nile tilapia respectively. The CPUE was from hydroacoustic (Nile perch and Dagaa) and trawl (Nile tilapia) surveys and was only consistent for the species since 1999. The CPUE was restricted to 2015 beyond which no catch data are available.

\section{Catch data used for the whole lake was partly available from} Nyamweya et a1. (2016) and was supplemented with data from the archives of the National Fisheries Resources Research Institute. The archives were the sources of the catch data for the Ugandan part.

Productivity of a stock is reflected in CMSY as prior ranges of intrinsic rate of population increase $(r)$ which are derived by classifying resilience of species available in FishBase into $r$ values (Froese \& Pauly, 2015; Froese \& Pauly, 2019). The resilience of Dagaa is high and that of Nile tilapia and Nile perch is medium. Their respective $r$ ranges are $0.6-1.5,0.2-0.8$ and $0.2-0.8$ (Froese \& Pau1y, 2019; Froese et a1. 2017).

The $\mathrm{B} / \mathrm{k}$ prior ranges depend on depletion status of stocks: very strong depletion $(0.01-0.2)$, strong depletion $(0.01-0.4)$, medium depletion $(0.2-0.6)$, low depletion $(0.4-0.8)$, and nearly unexploited $(0.75-1.0)$ (Froese et a1. 2019). These are required for the start, intermediate and end year of the time series. We harnessed trends in biomass and catches over the time series to set the $B / k$ ranges for the species (Figure 1 ).

The start years for the Nile perch, Nile tilapia and Dagaa were $1965,1971,1968$ respectively in the first scenario for the whole 1ake 
157

using absolute biomass, and 1999 for the second whole lake scenario using CPUE and the Ugandan part. The end year was 2015 in both scenarios.

For the first whole lake scenario, the $\mathrm{B} / \mathrm{K}$ ranges at the start years were set at low depletion for a11 the stocks (Table 1). In these years, the stocks were at the initiation fishery development phase and the low depletion enabled the future development of their fisheries (Hilborn \& walters, 1992; Figure 1). At the end, the Nile perch fishery had reached the decline phase of fishery development (Hilborn \& walters, 1992; Figure 1) which was characterized by high fishing effort (Nyamweya et a1. 2020). For this reason, we set the $\mathrm{B} / \mathrm{k}$ priors to strong depletion. For Nile tilapia, by 2015 , although the catch in the whole lake was not the lowest ever, it was $10.3 \%$ of the historical maximum, guiding us to set the $B / K$ prior to very strong depletion. For Dagaa, the catch was increasing albeit decreasing biomass. Given its high turnover rate and high fishing pressure (Mangeni-sande et al. 2019), we set its $B / K$ priors to medium.

The intermediate year is a year in the development of a fish stock such as when biomass, exploitation or recruitment was low or high (Froese et a1. 2019). We set the intermediate years for the stocks at years when biomass was highest i.e. 1989 for Nile perch, 1991 for Nile tilapia and 2000 for Dagaa. For the Nile perch and Nile tilapia stocks, the intermediate years were at the time fishery development was declining (Figure 1 ), prompting us to set the $B / k$ priors to strong depletion (Table 1 . For Dagaa, medium depletion was selected.

In the scenarios of CPUE as the index of abundance, we set the $B / k$ priors at the start (1999) for the whole lake and Ugandan part at strong depletion for Nile perch and Nile tilapia, and medium depletion for Dagaa based on guidance from trends in biomass. The end year $\mathrm{B} / \mathrm{K}$ priors were maintained as above for both spatial scales. The intermediate years for the Ugandan part were set at 2005 for al1 the stocks, corresponding to a period when fishing effort, catch, and CPUE were highest or lowest. The corresponding intermediate $\mathrm{B} / \mathrm{k}$ priors were set at strong depletion for Nile perch and Nile tilapia, and medium depletion for Dagaa. This was similar for the whole lake only that the intermediate years were 2005 for Nile tilapia, 2008 for Nile perch and 2007 for Dagaa. 
198

Fina11y, a recent period of at least 5 years when catch and abundance were relatively stable or had similar trends is required for determining catchability coefficient to relate CPUE to biomass. The default of the 1 ast 5 years was selected for a11 the stocks except Dagaa in the whole lake whose catches and abundance had different trends (Figure 1). We chose a period from 2000-2004 when biomass and catches for Dagaa in the whole lake were stable.

The CMSY/BSY were implemented in R using the code for the methods (Froese et a1. 2019). Data used are available online (Musinguzi, 2020). Palomares et al. (2018) established an approach of classifying fish stocks as collapsed, recruitment impaired, overfished, or healthy, basing on estimates of $B / B_{m s y}$. This was used to define the status of the stocks assessed.

\section{Results and discussion}

For the whole lake, the two indices of abundance used returned comparable estimates of the fisheries reference points because values in both scenarios were largely overlapping and falling within each other's confidence intervals (Table 2; supplementary table 1). For this reason estimates with CPUE as the index of abundance were adopted for further consideration. In addition, CPUE is the most preferred for the methods used (Froese et a1. 2017) and its results were more precautionary for most of the stocks. Tables 2 and 3 present the estimates of the reference points and stock status determined for the whole lake and Ugandan part respectively. Figures 2,3 and 4 illustrate the reference points and status for Nile perch in Uganda as an example, with illustrations of other stocks available in supplementary material 1 .

In Uganda, the stock status of Nile tilapia and Nile perch was recruitment impaired, and Dagaa health. Nile tilapia stock was tending more towards collapsed status while Nile perch and Dagaa stocks were tending more towards overfished status (Table 4). For the whole lake, the stock status of Nile tilapia, Nile perch and Dagaa was collapsed, overfished and health respectively. The Nile perch and Dagaa stocks were respectively tending more towards recruitment impaired and overfished status (Table 4).

Our results confirm widespread overfishing for Nile tilapia and Nile perch. The poor status corresponds to poor fishing practices and intensive fishing pressure that have characterized the fisheries of 
240

241

242

243

244

245

246

247

248

249

250

251

252

253

254

255

256

257

258

259

260

261

262

263

264

265

266

267

268

269

270

271

272

273

274

275

276

277

278

279

280

281

the stocks for a longtime (Nyamweya et a1. (2020). Njiru et a1. (2007) assessed the two stocks in Kenya and observed high recruitment overfishing with $98 \%$ of Nile perch and $60 \%$ of Nile tilapia 1 anded immature, high fishing mortality rate and degradation in 1ife history. The degradation in life history in response to intensive fishing was found to be lake wide (Njiru et a1. 2008).

The high fishing pressure and its persistence in the lake are consistent with our estimates of exploitation. In Uganda, exploitation has been above the reference level since 2006 for Nile perch (Figure 2 bottom right; Figure 3E) and 2003 for Nile tilapia (supplementary Figure 1 bottom right; supplementary Figure 2E). At around the same time, exploitation has since been above reference level for the stocks in the whole 1ake. As a result, we observed degradation in stock size depicted in declining $B / B_{\text {msy }}$ (Figure 2 top right) and $B / K$ (Figure 3D). See corresponding supplementary figures for other stocks.

Exploitation was higher for Nile tilapia stocks hence its worse status compared to Nile perch (Tables $2,3 \& 4$ ). We presume that the Nile perch stock status would be worse than it is were it not for its high fecundity and pseudo protected areas offshore where fishing is probably restricted by distance and severity of weather. Nile perch individuals can obtain absolute fecundity of 16.8 million depending on size (ogutu-ohwayo, 1988). This contrasts with the Nile tilapia whose mean absolute fecundity is 837 (Natugonza et a1. 2016). The poor status of the two stocks is collectively illustrated in the Kobe plots which indicate that the stocks are $97.8 \%$ (Nile perch) and $100 \%$ (Nile tilapia) unsustainable in Uganda (Figure 4; supplementary figure 3 ) and $99.9 \%$ (Nile tilapia) and 99.1\% (Nile perch) in the whole lake, requiring urgent management interventions

Dagaa, unlike the other stocks had health stock status in Uganda and the whole lake. The health status is depicted in low exploitation which has mainly been below the reference level (supplementary Figure 4 bottom right; supplementary Figure 5E; supplementary Figure 13 bottom right; supplementary Figure 14E). The health stock status cannot be attributed to good management which has been limited in the lake (Njiru et a1. 2007). Indeed, fishing pressure on the stock has intensified because the number and panels of seines used to target it have increased while mesh sizes have declined (Mangeni-sande et a1. 2019). We attribute the better status of the 
282

283

284

285

286

287

288

289

290

291

292

293

294

295

296

297

298

299

300

301

302

303

304

305

306

307

308

309

310

311

312

313

314

315

316

317

318

319

320

321

322

stock to the high resilience of the species (Froese \& Pauly, 2019). Dagaa has ability to double its biomass in $<15$ months and this is likely the reason it can bounce back from the high fishing pressure. Nevertheless, management needs to pay attention because the fishery is 17.7-30.2\% unsustainable (supplementary figures $6 \& 15$ ) and tending more towards overfished status in both the whole lake and Ugandan part (Table 4).

Our estimates of MSY provide with managers, the fisheries potential of the stocks under good management. The MSY estimates for Nile perch and Nile tilapia were more than the most recent catches in the Ugandan part and the whole lake (Table 5). In Uganda, rebuilding the Nile tilapia and Nile perch stocks to MSY level could increase the catches of the stocks by $9.2 \%$ and $29.5 \%$ above the most recent catches respectively. At the whole lake leve1, the same intervention could increase the catches of the two stocks by $72.8 \%$ and $15.1 \%$ respectively (Table 5). To realize these benefits, managers should, in management objectives include rebuilding biomass of Nile tilapia and Nile perch to $B_{m s} 1$ evels which were in al1 cases more than the current (2015) biomass (Table 2, $3 \& 4$ ). Estimates of biomass available for Nile perch since 2017 when enforcement was strengthened show that this is possible through eliminating illegal fishing practices (Hydro-acoustics Regional Working Group, 2019). The mean biomass of Nile perch in the whole lake in 2019 was 816,694 tonnes, with 705,458 tonnes as the lower 1imit and 940,922 tonnes as the upper limit. This was more than the biomass in 2015 and $24.4 \%$ less than $B_{m s y}$ (Table 3). In Uganda, the mean biomass was 422,076 tonnes with lower and upper 1imits of 366,757and 485,694 tonnes respectively which was also more than the 2015 biomass and only 11.3\% 1ess than $B_{\text {msy }}$ (Table 2). These values indicate that the current biomass $B_{m s}$ gap is closing faster in Uganda compared to the whole 1ake. The recovery for the whole lake is probably constrained by Kenya which unlike Uganda and Tanzania, has not strengthened enforcement. Kenya should copy.

Unlike Nile tilapia and Nile perch, the MSY estimates for Dagaa were lower than recent catch. This means that much more is being taken than is supported by standing biomass, the same process that gradually brought about the observed poor status of the Nile tilapia and Nile perch stocks. 


\section{Conclusion}

The major objective of management on Lake Victoria should be rebuilding biomass of Nile tilapia and Nile perch to a level that can support catches at MSY. Eliminating illegal fishing practices has proved to be an effective way to achieve this because of the observed increase in biomass of Nile perch since 2017 when enforcement in Uganda and Tanzania was strengthened (Hydro-acoustics Regional working Group, 2019). Kenya should do the same while Tanzania and Uganda should strengthen to close the gap between the current biomass and $B_{m s y}$.

After elimination of illegal fishing practices, the next task of management should be to ensure that catches remain 1 ow unti 1 biomass is $\geq B_{m s y}$ for at least three consecutive years (Froese et a1. 2017).

After rebuilding, catches could be increased to MSY although a precautionary measure according to FAO is to exploit at the lower boundary of MSY (Tables 2 \& 3) to guard against inefficiencies in enforcement and natural dynamics of fish stocks (Caddy et a1. 1984). The precautionary measure could also cater for uncertainties in data due to unreported catches and cross border fishing and fish trade which are common on Lake Victoria (Heck et a1. 2004). cross border fishing and trade could lead to uncertainties in estimates of reference points especially at country leve1. For example, Kenyan fishers and traders who confessed to extensive cross-border fishing and trade give Kenya more catches than expected, a source of uncertainty (Geheb, 1997; Matsuishi et a1. 2006). Indeed, our MSY estimates for Nile perch and Nile tilapia in Uganda (Table 3) are trumped by MSY estimates of 86,096 tonnes and 27,892 tonnes for the stocks respectively in Kenya (Aura et a1. 2020). Cross border fishing and trade is the only plausible explanation for this.

To facilitate these interventions, routine data collection, preferably at an annual scale is indispensable to monitor biomass and catches to support stock assessments such as this to guide and evaluate management measures. Data collection has been a challenge particularly in Uganda. For instance, since 2015, no catch assessment surveys have been done in the Ugandan part of Lake victoria which is regrettable. 


\section{Acknowledgement}

We are grateful to funders who supported projects from which the data used in this study were generated.

\section{References}

Aura, C. M., Nyamweya, C. S., Owi1i, M., Gichuru, N., Kundu, R., Njiru, J. M., \& Ntiba, M. J. (2020). Checking the pulse of the major commercial fisheries of Lake Victoria Kenya, for sustainable management. Fisheries Management and Ecology, $27(4), 314-324$.

Caddy, J.F. (1984) An Alternative to Equilibrium Theory for Management of Fisheries. In FAO (1984) Papers presented at the Expert Consultation on the regulation of fishing effort (fishing mortality). Rome, 17-26 January 1983. A preparatory meeting for the FAO World Conference on fisheries management and development. FAO Fisheries Report No. 289 Supp1. 2, 214 p.

Cooke, S. J., Allison, E. H., Beard, T. D., ... \& Welcomme, R. L. (2016). On the sustainability of inland fisheries: Finding a future for the forgotten. Ambio, 45(7), 753-764. https://doi .org/10.1007/s13280-016-0787-4

FAO, MSU. (2015). The Rome Declaration: Ten steps to Responsible Inland Fisheries. http://www.fao.org/3/a-i5735e.pdf. Rome, Itaךy.

FAO. (2020). The State of World Fisheries and Aquaculture 2020. Sustainability in action. Rome. https://doi.org/10.4060/ca9229en

Froese, R. and D. Pauly. Editors. 2019. FishBase. world wide web electronic publication. www.fishbase.org, version (12/2019).

Froese, R., Demire1, N., Coro, G. and Winker, H. 2019. A Simple User Guide for CMSY+ and BSM (CMSY_2019_9f.R). http://oceanrep.geomar.de/33076/ in December 2019. Accessed February 2020.

Froese, R., Demire1, N., Coro, G., Kleisner, K. M., \& Winker, H. (2017). Estimating fisheries reference points from catch and resilience. Fish and Fisheries, 18(3), 506-526.

Geheb K. (1997) The Regulators and the Regulated: Fisheries Management, options and Dynamics in Kenya's Lake Victoria Fishery. D. Phi1. Thesis, Brighton: University of Sussex, 287 $\mathrm{pp}$.

Heck, S., Ikwaput, J., Kirema-Mukasa, C. T., Lwenya, C., Murakwa, D. N., Odongkara, K., ...\&\& Sobo, F. (2004). Cross-border Fishing 
405

406

407

408

409

410

411

412

413

414

415

416

417

418

419

420

421

422

423

424

425

426

427

428

429

430

431

432

433

434

435

436

437

438

439

440

441

442

443

444

445

446

and Fish Trade on Lake Victoria. Fisheries Management Series, Vol 1, 82pp.

Hilborn, R., \& Walters, C. J. (Eds.). (1992). Quantitative fisheries stock assessment: choice, dynamics and uncertainty. Springer Science \& Business Media.

Hydro-acoustics Regional working Group, 2019. A report of the lake-wide hydro-acoustic survey. LVFo, Jinja, Uganda

Mangeni-Sande, R., Taabu-Munyaho, A., Ogutu-ohwayo, R., Nka7ubo, W., Natugonza, V., Nakiyende, H., ... \& Muwanika, V. B. (2019). Spatial and temporal differences in 1 ife history parameters of Rastrineobola argentea (Pellegrin, 1904) in the Lake Victoria basin in relation to fishing intensity. Fisheries Management and Ecology, 26(5), 406-412.

Marsha11, B. E., \& Mkumbo, O. C. (2012). The fisheries of Lake Victoria: past, present and future. Nature \& Faune, 26(1), 813 .

Matsuishi, T., Muhoozi, L., Mkumbo, o., Budeba, Y., Njiru, M., Asila, A., ...\& \& cowx, I. G. (2006). Are the exploitation pressures on the Nile perch fisheries resources of Lake Victoria a cause for concern? Fisheries Management and Ecology, 13(1), 53-71.

Mudliar, P. 2018. Fire on the water: Militarization of Fisheries Management on Lake Victoria. Retrieved from https://securefisheries.org/news/militarization-fisheries-1akevictoria

Musinguzi, Laban (2020): Data used for determining status and targets for rebuilding the three major fish stocks in Lake victoria. figshare. Dataset.

https://doi.org/10.6084/m9.figshare.13108289.v1

Natugonza, V., ogutu-ohwayo, R., Efitre, J., ...\& Sharon, N. (2015). The responses of $N$ ile tilapia o reochromis niloticus ( $L$ innaeus, 1758) in $L$ ake $W$ amala ( $U$ ganda) to changing climatic conditions. Lakes \& Reservoirs: Research \& Management, 20 (2), 101-119.

Njiru, M., Kazungu, J., Ngugi, C. C., Gichuki, J., \& Muhoozi, L. (2008). An overview of the current status of Lake Victoria fishery: Opportunities, challenges and management strategies. Lakes \& Reservoirs: Research \& Management, 13(1), 1-12.

Njiru, M., Nzungi, P., Getabu, A., Wakwabi, E., Othina, A., Jembe, T., \& Wekesa, S. (2007). Are fisheries management, measures in Lake Victoria successful? The case of Nile perch and Nile tilapia fishery. African Journal of ecology, 45(3), 315. 
NPA, 2019. Mid-term review of the NRM manifesto 2016 - 2021. http: //www.npa.go.ug/wp-content/uploads/2020/06/NRM-ManifestoMTR-Report-2016-2021.pdf. Accessed 10th September 2020.

Nunan, F., Cepić, D., Yongo, E., Salehe, M., Mbilingi, B., Odongkara, K., ...\& \& Owili, M. (2018). Compliance, corruption and co-management: how corruption fuels illegalities and undermines the legitimacy of fisheries co-management. Internationa1 Journal of the Commons, 12(2).

Nyamweya, C. S., Natugonza, V., Taabu-Munyaho, A., Aura, C. M., Njiru, J. M., Ongore, C., ...\& \&ayanda, R. (2020). A century of drastic change: Human-induced changes of Lake Victoria fisheries and ecology. Fisheries Research, 230, 105564.

Nyamweya, C., Sturludottir, E., Tomasson, T., Fulton, E. A., TaabuMunyaho, A., Njiru, M., \& Stefansson, G. (2016). Exploring Lake Victoria ecosystem functioning using the Atlantis modeling framework. Environmental Model1ing \& Software, 86, 158-167.

Ogutu-Ohwayo, R. (1988). Reproductive potential of the Nile perch, Lates niloticus $L$. and the establishment of the species in Lakes Kyoga and Victoria (East Africa). Hydrobiologia, 162(3), 193-200.

Palomares, M. L., Froese, R., Derrick, B., ... \& Pauly, D. (2018). A preliminary global assessment of the status of exploited marine fish and invertebrate populations.

Trewavas, E (ed.). 1983. Tilapiine fishes of the genera Sarotherodon, oreochromis and Danakilia. British Museum (Natural History). London. 583p.

\section{Tables}

Table 1 Relative stock biomass (B/K) prior ranges used for the stocks. The ranges depend on the depletion status of stocks: very strong depletion $(0.01-0.2)$, strong depletion $(0.01-$ $0.4)$, medium depletion $(0.2-0.6)$, low depletion $(0.4-0.8)$, and nearly unexploited $(0.75$ - 1.0) (Froese et al. 2019)

\begin{tabular}{llccc}
\hline Spatial scale & stock & B start/k & $B_{\text {int }} / k$ & $B_{\text {end }} / k$ \\
\hline $\begin{array}{l}\text { Whole lake } \\
\text { (biomass) }\end{array}$ & Nile tilapia & $0.4-0.8$ & $0.01-0.4$ & $0.01-0.2$ \\
& Nile perch & $0.4-0.8$ & $0.01-0.4$ & $0.01-0.4$ \\
& Dagaa & $0.4-0.8$ & $0.2-0.6$ & $0.2-0.6$ \\
Whole 1ake & Nile tilapia & $0.01-0.4$ & $0.01-0.4$ & $0.01-0.2$ \\
(CPUE) & & & & \\
& Nile perch & $0.01-0.4$ & $0.01-0.4$ & $0.01-0.4$ \\
& Dagaa & $0.2-0.6$ & $0.2-0.6$ & $0.2-0.6$ \\
Uganda & Nile tilapia & $0.01-0.4$ & $0.01-0.4$ & $0.01-0.2$
\end{tabular}


bioRxiv preprint doi: https://doi.org/10.1101/2020.10.26.354639; this version posted October 27, 2020. The copyright holder for this preprint (which was not certified by peer review) is the author/funder, who has granted bioRxiv a license to display the preprint in perpetuity. It is made available under aCC-BY-NC 4.0 International license.
Nile perch
$0.01-0.4$
$0.01-0.4$
$0.01-0.4$
Dagaa
$0.2-0.6$
$0.2-0.6$
$0.2-0.6$

479 
Table 2. Lake wide estimates when abundance is fishery independent CPUE. Estimates are on based BSM with approximate $95 \%$ confidence limits in parentheses. Estimates for $F_{m s y}$, MSY and $B_{m s y}$ are 1 ong-term averages while others are for the last year in the dataset (2015).

\begin{tabular}{|c|c|c|c|c|c|c|}
\hline Stock & $F_{\text {msy }}(1 /$ year $)$ & $\begin{array}{c}\text { MSY }(1000 \\
\text { tonnes/year })\end{array}$ & $\begin{array}{c}\mathrm{B}_{\text {msy }}(1000 \\
\text { tonnes) }\end{array}$ & B (1000 tonnes) & F (1/year) & $\begin{array}{c}\text { Exploitation } \\
\left(\mathrm{F} / \mathrm{F}_{\mathrm{msy}}\right)\end{array}$ \\
\hline $\begin{array}{l}\text { Nile } \\
\text { tilapia }\end{array}$ & $0.0514(0.0308-0.0858)$ & $72.8(52-102)$ & $446(297-668)$ & $70.1(36.6-170)$ & $0.531(0.219-1.02)$ & $10.3(1.79-39.9)$ \\
\hline $\begin{array}{l}\text { Nile } \\
\text { perch }\end{array}$ & $0.228(0.135-0.384)$ & $246(206-294)$ & $1080(675-1727)$ & $547(365-774)$ & $-0.555)$ & $.09-3.65)$ \\
\hline Dagaa & $0.474(0.344-0.652)$ & $461(396-536)$ & $973(700-1351)$ & $1112(809-1361)$ & $0.484(0.395-0.665)$ & $1.03(0.781-1.46)$ \\
\hline
\end{tabular}


Table 3. Estimates for the Ugandan part of the 1ake. Estimates are based on BSM with approximate 95\% confidence 1 imits in parentheses. Estimates for $F_{m s y}$, MSY and $B_{m s y}$ are long-term averages while others are for the last year in the dataset (2015).

\begin{tabular}{|c|c|c|c|c|c|c|}
\hline Stock & $F_{\text {msy }}(1 /$ year $)$ & $\begin{array}{c}\text { MSY }(1000 \\
\text { tonnes/year })\end{array}$ & $\begin{array}{c}\text { B }_{\text {msy }}(1000 \\
\text { tonnes })\end{array}$ & B (1000 tonnes) & F (1/year) & $\begin{array}{c}\text { Exploitation } \\
\text { (F/ } \mathrm{F}_{\mathrm{msy}}\end{array}$ \\
\hline $\begin{array}{l}\text { Nile } \\
\text { tilapia }\end{array}$ & $0.082(0.0501-0.134)$ & $19.9((15.7-25.4)$ & $121(80.5-183)$ & $30.4(16.3-53.4)$ & $0.556(0.316-1.03)$ & $6.77(2.09-24.4)$ \\
\hline $\begin{array}{l}\text { Nile } \\
\text { perch }\end{array}$ & $0.136(0.0846-0.219)$ & $74.8(58-96.4)$ & $476(316-716)$ & $206(130-302)$ & $0.25(0.171-0.396)$ & $1.86(1.01-4.52)$ \\
\hline Dagaa & $0.433(0.312-0.6)$ & $95.4(80.6-113)$ & $220(158-306)$ & $242(164-310)$ & $0.446(0.348-0.656)$ & $1.04(0.738-1.62)$ \\
\hline
\end{tabular}


491 Table 4 stock status based on the classification of $B / B_{m s y}$ values by

Palomares et a7. 2018. In parentheses is the stock status each of the stocks is tending more towards.

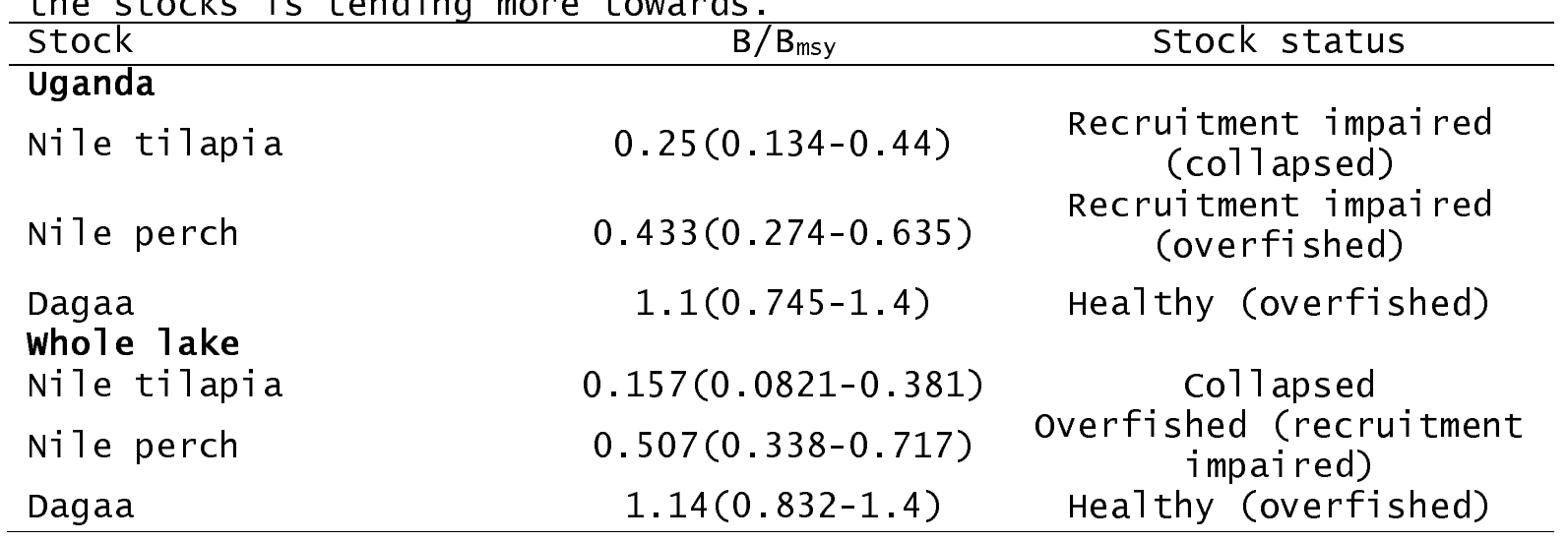


495 Table 5 Estimates of MSY for the stocks in relation to recent

496 catches (average for last three years (2013-2015).

\begin{tabular}{lcccc}
\hline Stock & $\begin{array}{c}\text { MSY (1000 } \\
\text { tonnes/year) }\end{array}$ & $\begin{array}{c}\text { Recent catch } \\
(1000 \\
\text { tonnes/year) }\end{array}$ & $\begin{array}{c}\text { Change } \\
\text { relative to } \\
\text { MSY }(1000 \\
\text { tonnes/year) }\end{array}$ & $\begin{array}{c}\text { Change relative } \\
\text { to recent catch } \\
\text { (\%) }\end{array}$ \\
\hline Nile tilapia_UG & 19.9 & 18.2 & 1.7 & 9.2 \\
Nile perch_UG & 74.8 & 57.8 & 17.0 & 29.5 \\
Dagaa_UG & 95.4 & 119.3 & -23.9 & -20.0 \\
Ni le tilapia & 72.8 & 42.1 & 30.7 & 72.8 \\
Nile perch & 246 & 213.6 & 32.4 & 15.1 \\
Dagaa & 461 & 519.8 & -58.8 & -11.3 \\
\hline
\end{tabular}


498

499

500

501

502

503

504

505

506

507

508

509

510

511

512

513

514

515

516

517

518

519

520

521

522

523

524

525

526

527

528

529

530

531

532

533

534

535

536

537

538

539

\section{Figure captions}

Figure 1. Trends in catches and absolute biomass for the three major commercial fish species on Lake Victoria. Catches are for the whole lake. Absolute biomass from Nyamweya et a1. (2016).

Figure 2. Trends in key management aspects of the Nile perch fishery in Lake Victoria, Uganda. The graphs show catches relative to MSY, with $95 \%$ confidence 1 imits in grey (upper 1eft); predicted relative tota 1 biomass $\left(B / B_{m s y}\right)$ with the grey area indicating uncertainty (upper right); relative exploitation ( $\left.F / F_{m s}\right)$ and corresponding $95 \%$ confidence limits in grey (lower 1eft); and stock status in relation to $B / B_{m s y}$ as a function of $F / F_{m s y}$ for the first (1965), intermediate (1989) and final (2015) years of assessment. The 50, 80 and $95 \%$ are Confidence levels around the assessment of the final year.

Figure 3. Results of the Nile perch fishery in Lake Victoria, Uganda. A shows time series in catch (black curve) and smoothed data with indication of highest and lowest catch (red curve). In B to $F$, red refers to estimates of BSM and blue to estimates of CMSY+. The crosses in $B$ show the best $r-k$ estimate of either methods (point in the center) and their 95\% confidence limits (horizontal and vertical error bars). In dark grey are the pairs found to be compatible with the catches and biomass. In $C$, the black and dark grey dots are the viable r-k pairs found by BSM and CMSY respectively, with indication of crosses for best estimates with $95 \%$ confidence limits. Curves in D show the BSM and CMSY+ predictions of biomass, the dots the biomass data scaled by BSM, the vertical blue lines the prior biomass ranges. E shows the predictions for exploitation and catch per biomass as scaled by BSM (dots). The curves in $F$ show the BSM and CMSY+ predictions of Schaufer equilibrium curves for catch/MSY relative to stock size (B/k) from the first (square) to the last year (triangle) of assessment, with the dots showing predicted catch per predicted biomass as scaled by BSM.

Figure 4. A Kobe plot for the Nile perch in the Lake Victoria, Uganda based on CMSY+ estimates of $B / B_{m s y}$ and $F / F_{m s y}$. A stock in the orange area is health but vulnerable to depletion by overfishing. In the red area, a stock is overfished and is undergoing overfishing, with too low biomass levels to produce maximum sustainable yields (MSY). In the yellow area, a stock is under reduced fishing pressure but recovering from too low biomass levels. The green area is the target area for management, indicating sustainable fishing pressure 
540 and healthy stock size capable of producing high yields close to

541 MSY. The probabilities of the Nile perch stock being in any of these

542 areas are given. the last year falling into one of the colored

543 areas. The 50,80 and $95 \%$ are confidence 1 evels around the year of

544 final assessment. The legend in the upper right graph also

545 indicates. 
bioRxiv preprint doi: https://doi.org/10.1101/2020.10.26.354639; this version posted October 27, 2020. The copyright holder for this preprint (which was not certified by peer review) is the author/funder, who has granted bioRxiv a license to display the preprint in perpetuity. It is made available under aCC-BY-NC 4.0 International license.

\section{Figures}

547 Figure 1
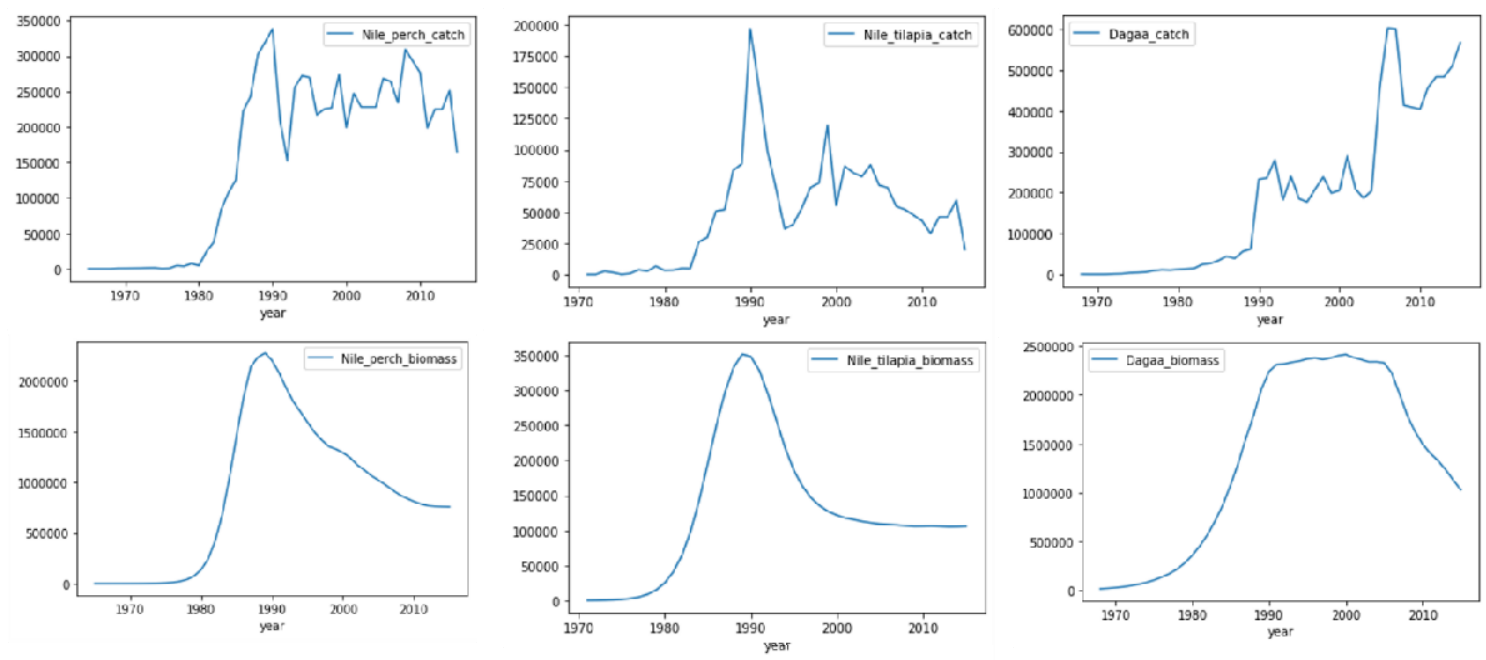
bioRxiv preprint doi: https://doi.org/10.1101/2020.10.26.354639; this version posted October 27, 2020. The copyright holder for this preprint (which was not certified by peer review) is the author/funder, who has granted bioRxiv a license to display the preprint in perpetuity. It is made available under aCC-BY-NC 4.0 International license.

549 Figure 2
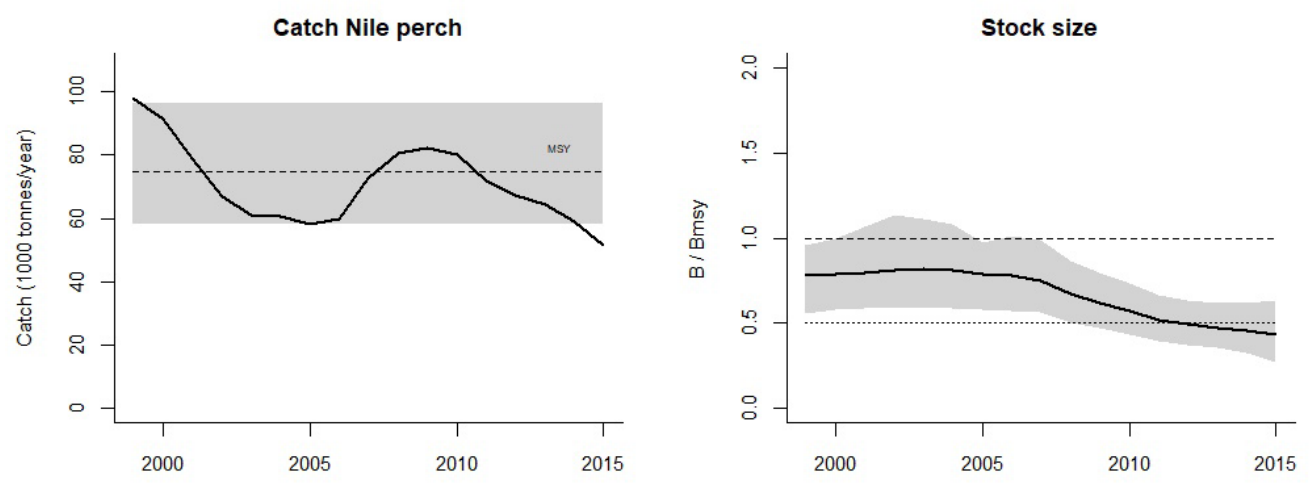

550
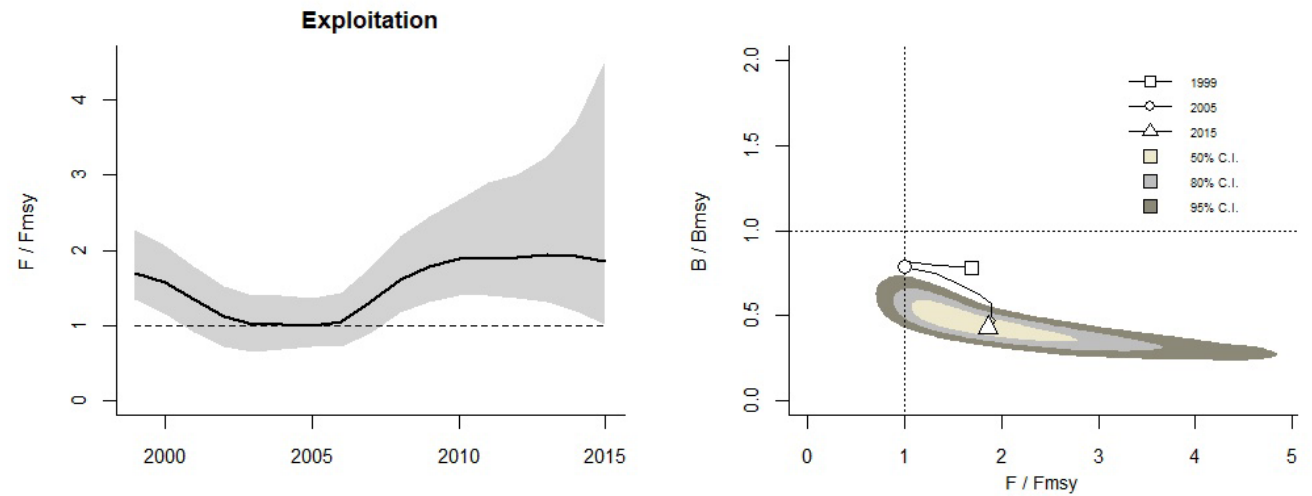
bioRxiv preprint doi: https://doi.org/10.1101/2020.10.26.354639; this version posted October 27, 2020. The copyright holder for this preprint (which was not certified by peer review) is the author/funder, who has granted bioRxiv a license to display the preprint in perpetuity. It is made available under aCC-BY-NC 4.0 International license.

551 Figure 3
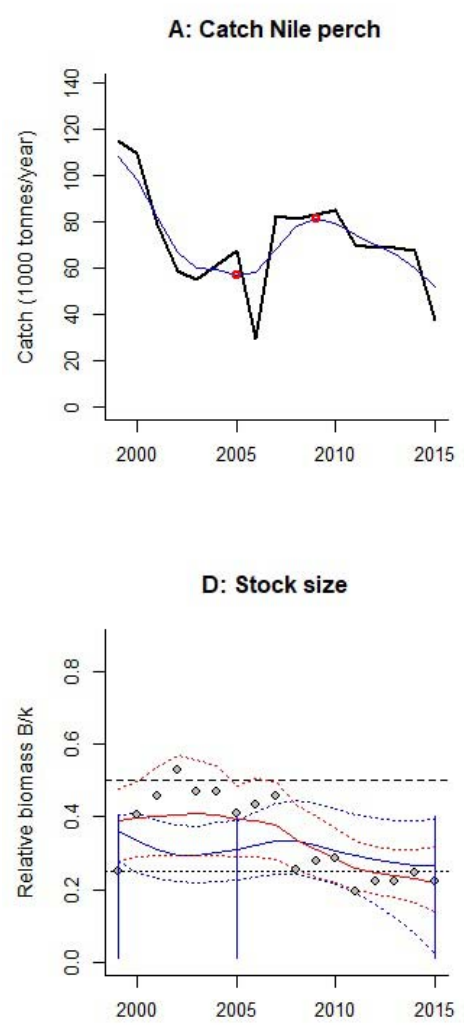

B: Finding viable r-k

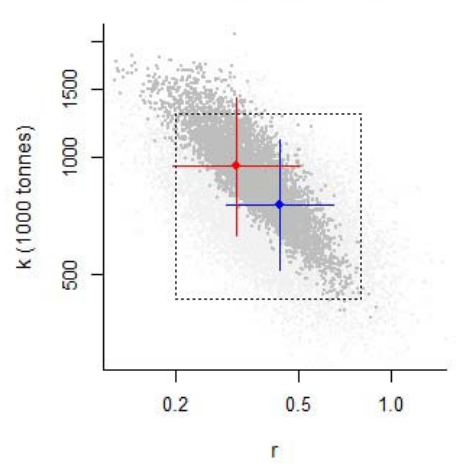

E: Exploitation rate

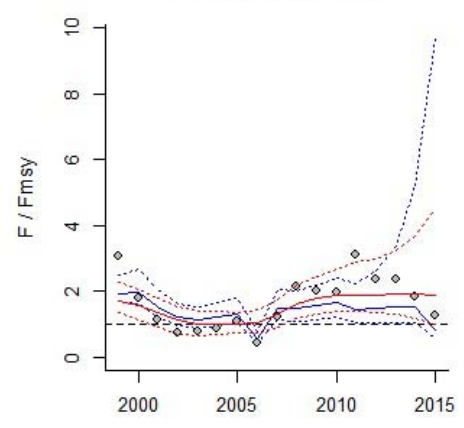

c: Analysis of viable r-k

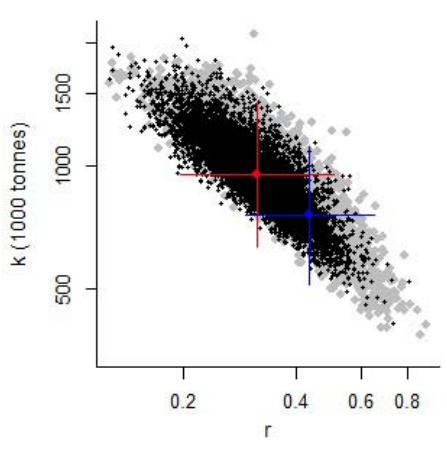

F: Equilibrium curve

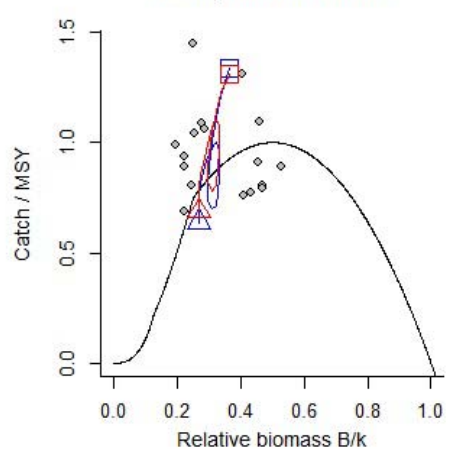

552 
bioRxiv preprint doi: https://doi.org/10.1101/2020.10.26.354639; this version posted October 27, 2020. The copyright holder for this preprint (which was not certified by peer review) is the author/funder, who has granted bioRxiv a license to display the preprint in perpetuity. It is made available under aCC-BY-NC 4.0 International license.

553

554
Figure 4

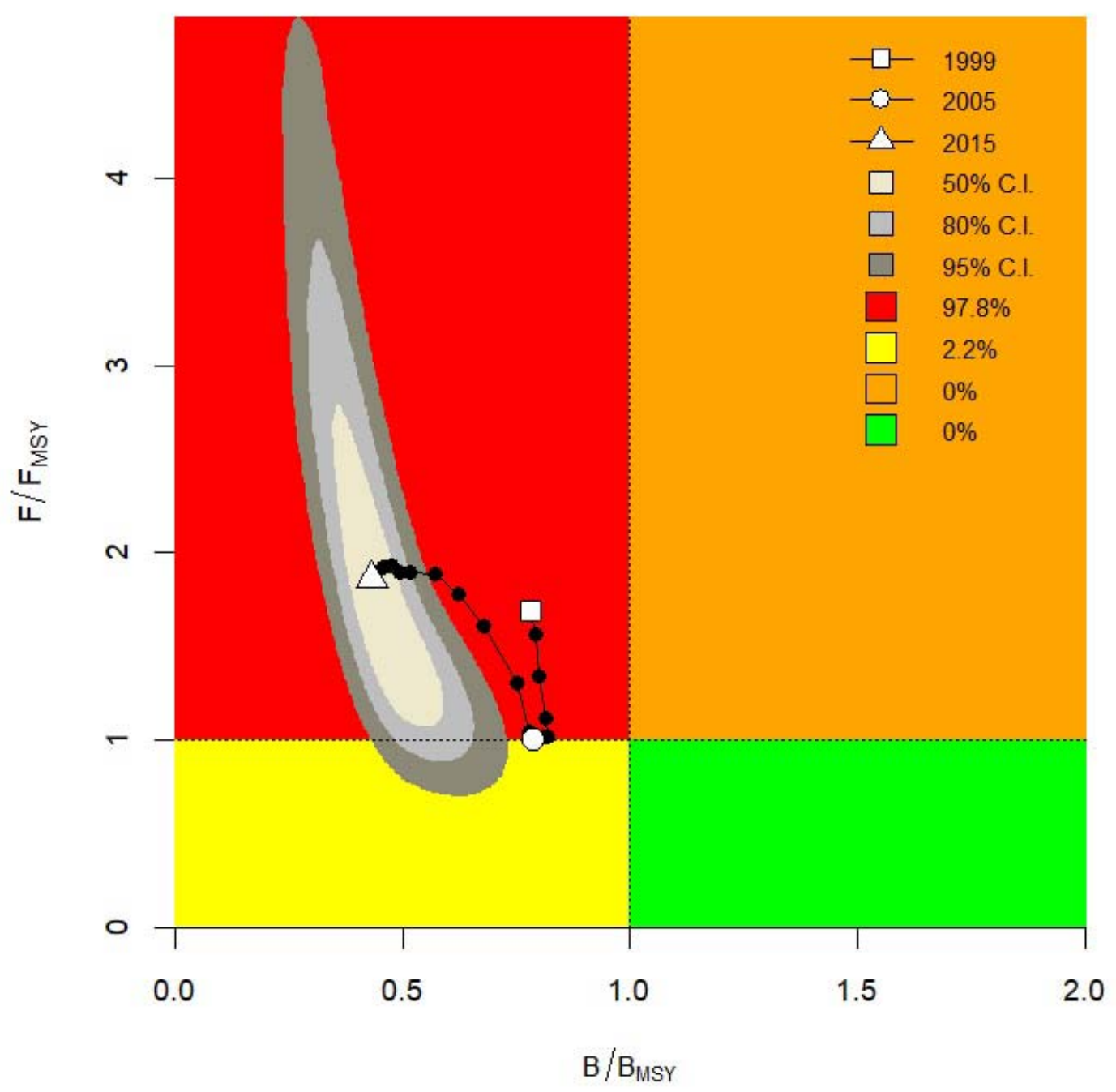

555 